\title{
IDENTIFIKASI DAN UJI PATOGENISITAS CENDAWAN ENTOMOPATOGEN LOKAL TERHADAP Leptocorisa oratorius
}

\section{IDENTIFICATION AND PATHOGENICITY TEST OF LOCAL ENTOMOPATHOGEN FUNGI AGAINST Leptocorisa oratorius}

\author{
Emmy Senewe dan Guntur S.J. Manengkey*) \\ *Dosen Jurusan Hama dan Penyakit Tumbuhan, Fakultas Pertanian Unsrat Manado_95115
}

\begin{abstract}
Leptocorisa oratorius is one major pest of rice in North Sulawesi. Hence, it is necessary to control the pest. The research objective was to identify and to test pathogenicity of local entomopathogen fungi which infected Leptocorisa oratorius. The pathogens were collected through sampling of $L$. oratorius which had been infected by the fungi in the field. The pathogenic fungi was isolated using PDA medium, identified followed by inoculation for pathogenecity test. During several sampling pest, it was found that $L$. oratorius was attacked by fungal pathogens in the field. The identification revelead that the fungal pathogens were Beauveria sp and Fusarium sp. Both the fungal pathogen produced white mycelium and could only be distinguished using microscope in the laboratory. Result of pathogenicity tests showed that the two fungal pathogens caused different mortality of the $L$. oratorius. Mortality of $L$. oratorius caused by pathogenic fungus Beauveria sp was $30.3 \%$. Whereas, mortality of $L$. oratorius caused by Fusarium sp was only $3.33 \%$.
\end{abstract}

Keywords : pathogenic fungi, entomopathogen, pathogenicity tests, L. oratorius

\begin{abstract}
ABSTRAK
Hama L. oratorius merupakan salah satu hama utama tanaman padi sawah di Sulawesi Utara, sehingga perlu dilakukan pengendalian. Tujuan penelitian adalah mengetahui jenis cendawan entomopatogen yang menginfeksi $L$. oratorius dan uji patogenesitas. Jenis patogen diperoleh melalui pengambilan contoh $L$. oratorius yang telah terinfeksi cendawan patogen di lapangan. Cendawan patogen tersebut disolasi pada media PDA, kemudian dilakukan inokulasi dan uji patogenisitas.

Selama beberapa kali pengambilan contoh hama $L$. oratorius yang terserang cendawan patogen di lapangan telah ditemukan dua jenis cendawan patogen. Jenis cendawan patogen yang menginfeksi $L$. oratorius adalah Beauveria sp dan Fusarium sp. Kedua cendawan patogen masa meisilum berwarna putih, dan hanya dapat dibedakan secara mikroskopis di laboratorium. Dari hasil pengujian patogenisitas menunjukkan bahwa mortalitas $L$. oratorius oleh kedua cendawan patogen tersebut berbeda. Mortalitas L. oratorius yang disebabkan oleh cendawan patogen Beauveria sp 30,3, sedangkan mortalitas $L$. oratorius yang disebabkan oleh cendawan patogen Fusarium sp adalah $3,33 \%$.
\end{abstract}

Kata Kunci: Jenis patogen cendawan, uji patogenisitas L. oratorius

Eugenia Volume 17 No. 3 Desember 2011 


\section{PENDAHULUAN}

Survei yang dilakukan oleh Tim Fakultas Pertanian Unsrat telah ditemukan 22 jenis serangga hama yang menyerang pertanaman padi sawah di Sulawesi Utara, namun hanya beberapa jenis serangga hama yang menimbulkan kerusakan cukup serius pada tanaman padi sawah, diantaranya $L$. oratorius, Pareucoemetus sp, Scirpophaga inotata, $S$. insertulas, $N$. virescens, $N$. nigropictus dan $C$. medinalis. Beberapa tempat pertanaman padi sawah di Minahasa Selatan, dan Minahasa Utara tidak memberikan hasil optimal, dikarenakan adanya serangan hama $L$. oratorius (Sembel, $d k k$., 2000). Kerusakan hama $L$. oratorius adalah mengisap bulir padi, akibat serangan hama ini menyebabkan pertumbuhan bulir padi kurang sempurna, biji tidak terisi penuh atau hampa sama sekali, dengan demikian akan mengakibatkan penurunan kualitas dan kuantitas hasil. Data kerusakan tanaman padi sawah oleh $L$. oratorius belum banyak dilaporkan, namun kerusakan yang ditimbulkan oleh serangga hama ini dipengaruhi oleh stadia masak dari malai padi, dimana kerusakan tertinggi terdapat pada saat malai masak susu. Jumlah biji padi terserang $L$. oratorius berdasarkan tingkat kemasakan malai padi adalah berbunga biji terserang 72,3 biji per 2 malai, masak susu biji terserang 86,5 biji per 2 malai, dan masak dengan butir keras 53,5 biji per 2 malai (Djuwarso, dkk., 1989).

Sembel dkk. (2000) melaporkan bahwa pengendalian serangga hama $L$. oratorius oleh petani sawah masih sangat tergantung pada insektisida. Aplikasi insektisida pada tanaman padi sawah sejak vegetatif sampai menjelang panen oleh petani 6 - 12 kali per musim tanam. Frekwensi aplikasi insektisida meningkat pada saat memasuki fase reproduktif, dikarenakan adanya serangan hama $L$. oratorius. Insektisida yang digunakan antara lain Dharmabass, Actara, Decis, Ambush, Proclaim dan Furadan. Aplikasi insektisida dilakukan secara terus menerus pada setiap musim tanam, bahkan aplikasi insektisida dilakukan secara bergantian pada berbagai jenis insektisida, bila insektisida tersebut tidak mampu menurunkan populasi hama.

Bila petani masih mengandalkan insektisida menyebabkan suatu produk akan kalah bersaing dengan produk tanpa insektisida yang disebut pertanian organik. Oleh karena itu sudah saatnya dilakukan pengendalian hama yang tidak menimbulkan masalah baru dan tidak mencemari lingkungan. Pengendalian serangga hama yang dapat menekan pengaruh negatif terhadap lingkungan adalah pemanfaatan cendawan entomopatogen lokal. Namun sampai saat ini belum diketahui jenis cendawan entomopatogen lokal yang menginfeksi $L$. oratorius di Sulawesi Utara terutama Minahasa Selatan. Hall (1973) mengemukakan keuntungan penggunaan cendawan entomopatogenik antara lain relatif aman, kapasitas reproduksi tinggi, siklus hidup pendek, bersifat selektif, kompatibel dengan pengendalian lainnya, relatif murah diproduksi dan kemungkinan menimbulkan resistensi amat kecil atau lambat, dan dapat membentuk spora yang dapat bertahan lama, bahkan dalam kondisi yang tidak menguntungkan sekalipun.

Steinhaus (1963) melaporkan bahwa lebih dari 915 mikroorganisme bersifat patogenik terhadap serangga termasuk kira-kira 25 spesies bakteri, 400 spesies virus dan riketsia, 255 spesies cendawan, 200 spesies protozoa dan 15 spesies nematoda. Di Indonesia, jenis cendawan patogen yang menginfeksi pada serangga hama $L$. oratorius adalah Beauveria bassiana, Metarhizium anisopliae dan M. flavoridae (Anonim, 1990; Kalshoven, 1981). Di Filipina, selain ketiga cendawan patogen yang dapat menginfeksi $L$. oratorius ditemukan pula Paccilomyces lilacinus (Rombach et. al., 1994) Di Sulawesi Utara, penelitian entomopatogen telah dilaporkan oleh Rimbing dkk. (2006) bahwa cendawan entomopatogen lokal yang mampu menginfeksi wereng hijau $N$. virescens, yaitu Fusarium sp., Glasdosporium sp., Beauveria sp., Metarhzium sp A, dan Metarhzium sp B.

Uji patogenisitas cendawan entomopatogen di Sulawesi Utara telah diteliti oleh Rimbing $d k$. (2006) bahwa mortalitas $N$. virescens oleh cendawan entomopatogen Cladosporium sp, dan Fusarium sp lebih kecil $50 \%$, sedangkan Metarhizium sp dan Beauveria sp. di atas $80 \%$ pada konsentrasi spora $1 \times 10^{8}$. Kemampuan cendawan entomopatogen $B$. bassiana pada konsentrasi $1,35 \times 10^{7} \mathrm{konidia} / \mathrm{ml}$ mortalitas mencapai $71,88 \%$, sedangkan konsentrasi spora 0,38 $\times 10^{7}$ 
konidia/ml hanya mampu mematikan hama $L$. oratorius 13,87\% (Tohidin, dkk., 1993).

Tujuan penelitian ini adalah mengetahui jenis cendawan entomopatogen yang menginfeksi L. oratorius dan uji patogenesitas.

\section{METODE PENELITIAN}

Penelitian telah dilaksanakan pada dua tempat, yaitu penelitian lapangan, laboratorium dan green house. Isolasi, uji Postulasi Kock dan patogenisitas pada $L$. oratorius di laboratorium dan green house lapangan.

\section{Pelaksanaan Penelitian}

Penetapan Lokasi Pengambilan Contoh

Pengambilan contoh $L$. oratorius yang terinfeksi cendawan patogen dilaksanakan pada 3 wilayah Kecamatan. Penetapan wilayah sebagai tempat pengambilan contoh serangga hama $L$. oratorius adalah sebagai berikut: Wilayah Kecamatan Tenga adalah Desa Radey, Pakuweru, Boyong; Wilayah Kecamatan Tumpaan adalah Desa Tumpaan 1, Matani dan Popontolen; Wilayah Kecamatan Tompasobaru adalah Desa Tompasobaru 1, Kuraweruan, dan Toraut.

Setiap desa ditentukan 2 tempat pengambilan contoh serangga hama $L$. oratorius. Jadi jumlah lokasi sebagai tempat pengambilan contoh serangga hama yang terserang cendawan untuk setiap wilayah kecamatan adalah 3 desa $\times 3$ tempat pengambilan $=9$ lokasi sebagai tempat pengambilan contoh. Ukuran contoh untuk setiap lokasi sebagai tempat pengambilan contoh adalah 1 ha.

Pengambilan contoh serangga hama $L$. oratorius yang terserang cendawan dilakukan 4 kali secara periodik yakni 2 minggu sekali dimulai 57 hst, dan 69 hst, dan 81 hst. Dilakukan pada umur tanaman 57 hst, karena hama $L$. oratorius sudah mulai menyerang tanaman padi sawah.

\section{Pemeliharaan Serangga Hama}

Pemeliharaan serangga hama $L$. oratorius dengan maksud mendapatkan stadia nimfa dan imago sebagai media yang akan diinokulasi dengan cendawan. Setiap kurungan kasa berukuran $1 \times 1 \mathrm{x}$ $1,25 \mathrm{~m}$ dimasukkan 1 ember plastik yang telah berisi tanaman padi sawah yang telah menghasilkan malai. Serangga hama dewasa atau imago yang diambil dari lapang kemudian dimasukkan ke dalam kurungan kasa, sebanyak 25 pasang. Percobaan ini diulang sebanyak 3 kali, sehingga dibutuhkan 75 pasang / 3 kurungan kasa.

\section{Penetapan Cendawan patogen (Postulat Koch)}

Tahap pertama dilakukan isolasi cendawan pada media PDA (Potato Dextrose Agar) untuk mendapatkan jenis-jenis cendawan yang menimbulkan penyakit pada hama $L$. oratorius.

Dari hasil isolasi cendawan pada media PDA belum diketahui secara pasti bahwa cendawan tersebut merupakan penyebab terjadi infeksi pada $L$. oratorius. Oleh karena itu untuk menetapkan penyebab terjadi infeksi hama $L$. oratorius, maka cendawan tersebut perlu diinokulasi pada $L$. oratorius yang sehat dari hasil pemeliharaan serangga di green house. Sebanyak 10 ekor nimfa instar 4 dimasukkan ke dalam tabung reaksi yang telah ditetesi $4 \mathrm{ml}$ suspensi spora, demikian pula dengan imago. Serangga yang berada dalam tabung reaksi dibiarkan selama 20 menit, dan selanjutnya nimfa dan imago dilepaskan pada kurungan kasa yang sudah tersedia tanaman padi sawah. Pengamatan dilakukan setiap hari untuk mendapatkan serangga yang mati selama 10 hari setelah dilakukan inokulasi. Selanjutnya serangga tersebut diinkubasi selama 3 - 5 hari, kemudian diisolasi kembali ke media PDA.

\section{Uji Tingkat Patogenisitas Cendawan Entomopatogen}

Dosis spora untuk mengukur patogenisitas dari setiap cendawan adalah $1 \times 10^{8}$. Penyemprotan suspensi pada hama $L$. oratorius dilakukan saat setelah imago dimasukkan ke dalam kurungan kasa. Jumlah cairan semprot yang diaplikasi pada rumpun tanaman padi sawah adalah $20 \mathrm{ml} /$ rumpun/ kurungan kasa.

Dalam percobaan ini ditemukan 2 jenis cendawan patogen, maka jumlah imago yang diperlukan dalam percobaan ini adalah 2 jenis $\times 3$ ulangan $\times 20$ individu $=120$ individu. Dalam pengujian patogenisitas, hal-hal yang diamati adalah gejala serangan, waktu timbulnya gejala, lamanya kematian imago $L$. oratorius pada setiap cendawan 
patogen dan jumlah mortalitas $L$. oratorius dari masing-masing cendawan. Pengamatan dilakukan setiap hari setelah dilakukan inokulasi sampai 14 hari di green house.

Persentase mortalitas $L$. oratorius dapat dihitung dengan menggunakan rumus yang dikemukakan oleh Finney (1952).

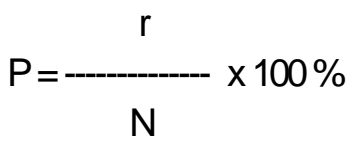

$\mathrm{P}=$ Persentase mortalitas $L$. oratorius

$r=$ Jumlah imago yang mati karena patogen

$\mathrm{N}=$ Jumlah imago yang diamati

\section{Pengamatan}

Pengamatan cendawan entomopatogen adalah sebagai berikut : Pengamatan morfologi konidia, hifa, konidiophore dan warna koloni cendawan pathogen; gejala serangan dari patogen pada serangga hama $L$. oratorius setelah diinokulasi; menghitung mortalitas $L$. oratorius pada setiap cendawan entomopatogen; lamanya kematian serangga hama $L$. oratorius pada masing-masing cendawan entomopatogen setelah dilakukan inokulasi; waktu terbentuknya mycelium dan spora pada permukaan tubuh serangga dari masing-masing cendawan entomopatogen

\section{Identiflkasi}

Identifikasi patogen dilakukan sampai tingkat famili, genus dan species berdasarkan pada morfologi konidia, hifa, konidiophore dan warna koloni. Kunci identifikasi patogen yang digunakan adalah Alexopoulus dan Mins (1979); Anonim (1990), Samson (1981); Burgess dan Hussey (1971); Poinar dan Thomas (1984).

\section{Analisis Data}

Data yang diperoleh dari uji patogenisitas cendawan patogen telah dilakukan analisis statistik deskriptif.

\section{HASIL DAN PEMBAHASAN}

\section{Jenis Cendawan Patogen}

Sebelum mendapatkan inokulum cendawan patogen pada $L$ oratorius, terlebih dahulu dilakukan pengambilan contoh serangga hama $L$. oratorius nimfa dan imago di lapangan yang terserang atau terinfeksi cendawan patogen di Kecamatan Tenga, Kecamatan Tumpaan dan Kecamatan Tompasobaru. Serangga hama $L$. oratorius yang terserang cendawan patogen pada masing-masing lokasi pengambilan contoh dapat diikuti pada Tabel 1.

Sebagaimana tercatum pada tabel 1 bahwa semua lokasi sebagai tempat pengambilan contoh ditemukan serangga hama $L$. oratorius terserang cendawan patogen. Cendawan patogen tersebut tidak hanya terbatas pada imago yang diserang, tetapi ditemukan pula pada stadia nimfa. Morfologi cendawan patogen yang ditemukan pada hama $L$. oratorius masing-masing lokasi tidak berbeda. Semua cendawan yang ditemukan selama pengambilan contoh yakni micilum berwarna putih. Hama $L$. oratorius yang terserang cendawan patogen ditemukan pada tanaman padi sawah kurang lebih $5-20 \mathrm{~cm}$ dari permukaan tanah pada batang tanaman padi sawah. Contoh cendawan patogen yang ditemukan pada hama $L$. oratorius dapat diikuti pada gambar 1.

Populasi hama $L$. oratorius terserang cendawan patogen yang ditemukan pada masingmasing lokasi lebih dari 2 individu, sehingga untuk satu kecamatan dapat ditemukan 5 - 15 individu yang terserang cendawan patogen. Untuk lokasi yang banyak ditemukan terserang cendawan patogen terdapat di Kecamatan Tenga, rata-rata 10-15 individu. Menurut DeBach (1964) bahwa perkembangan musuh-musuh alami mengikuti perkembangan dari populasi serangga hama yang terdapat pada ekosistem tanaman tersebut. Bila populasi serangga hama cukup banyak sudah tentu populasi yang terkena cendawan patogen menjadi cukup banyak pula.

Masa koloni yang ditemukan pada hama L. oratorius di masing-masing lokasi pengambilan contoh tidak bervariasi. Koloni dari cendawan patogen yang ditemukan di lapangan berwarna putih. Masa koloni antara Beauveria sp. dan Fusarium sp. berwarna putih dan sulit dibedakan secara visual di lapangan maupun di laboratorium. Kedua jenis patogen tersebut hanya mampu dibedakan secara mikroskopis setelah dilakukan isolasi pada media PDA di laboratorium. Masa koloni 
tersebut diambil sebagiannya kemudian diisolasi pada media PDA. Dari hasil pengujian Postulat Koch telah ditemukan dua jenis cendawan entomopatogen yang dapat menginfeksi nimfa dan imago L. oratorius yakni Beauveria sp dan Fusarium sp. Dari pengamatan secara makroskopis kedua cendawan di lapangan sulit dibedakan, dan hanya mampu dibedakan secara mikroskopis di laboratorium. Cendawan Beauveria sp micelium dan konidia (spora) yang dihasilkan berwarna putih, bentuknya oval dan tumbuh secara zig-zag pada konidiofornya, sedangkan cendawan Fusarium sp membentuk miselium sama seperti Beauveria sp yakni berwarna putih, tetapi jamur Fusarium sp. membentuk 2 jenis konidia yakni mikrokonidia dan makrokonidia. Mikrokonidia tidak memiliki sekat, sedangkan makrokonidia memiliki 2-3 sekat dan membentuk seperti bulan sabit. Rimbing dkk. (2006) melaporkan bahwa cendawan Beauveria sp dan Fusarium sp. menginfeksi hama wereng hijau pada pertanaman padi sawah di Sulawesi Utara. Cendawan patogen Beauveria sp. lebih efektif menginfeksi hama wereng hijau dibandingkan dengan
Fusarium sp. Diduga jenis cendawan Beauveria sp yang menyerang $L$. oratorius memiliki strain yang sama dengan strain cendawan Beauveria sp yang menyerang wereng hijau di Sulawesi Utara.

\section{Uji Patogenistas Cendawan Patogen}

Dari hasil uji patogenisitas kedua cendawan tersebut hanya mampu menurunkan populasi L. oratorius di bawah $40 \%$ dengan konsentrasi spora yang digunakan dalam percobaan ini $1 \times 10^{8}$. Infeksi cendawan Beauveria sp pada imago $L$ oratorius, setelah dilakukan aplikasi di kurungan kasa dan kemudian dibiakan selama beberapa hari di laboratorium dapat dilihat pada gambar 2 .

Dari hasil pengamatan menunjukkan bahwa serangga hama $L$. oratorius terserang patogen baik Beauveria sp dan Fusarium sp, kurang aktif bergerak sampai mengalami kematian. Setalah hama tersebut mati beberapa hari kemudian muncul miselium pada bagian tubuh serangga imago $L$. oratorius.

Tabel 1. Hama L. oratorius yang Ditemukan terserang Cendawan Patogen Pada Masing-Masing Lokasi Pengambilan Contoh

(Table 1. Pest L. oratorius is found attacked by fungus pathogens at Each Sampling Location)

\begin{tabular}{clc}
\hline No & \multicolumn{1}{c}{ Lokasi } & Terserang Cendawan \\
\hline 1 & Kecamatan Tenga & $\sqrt{ }$ \\
2 & Kecamatan Tumpaan & $\sqrt{ }$ \\
3 & Kecamatan Tompasobaru & $\sqrt{ }$ \\
\hline
\end{tabular}

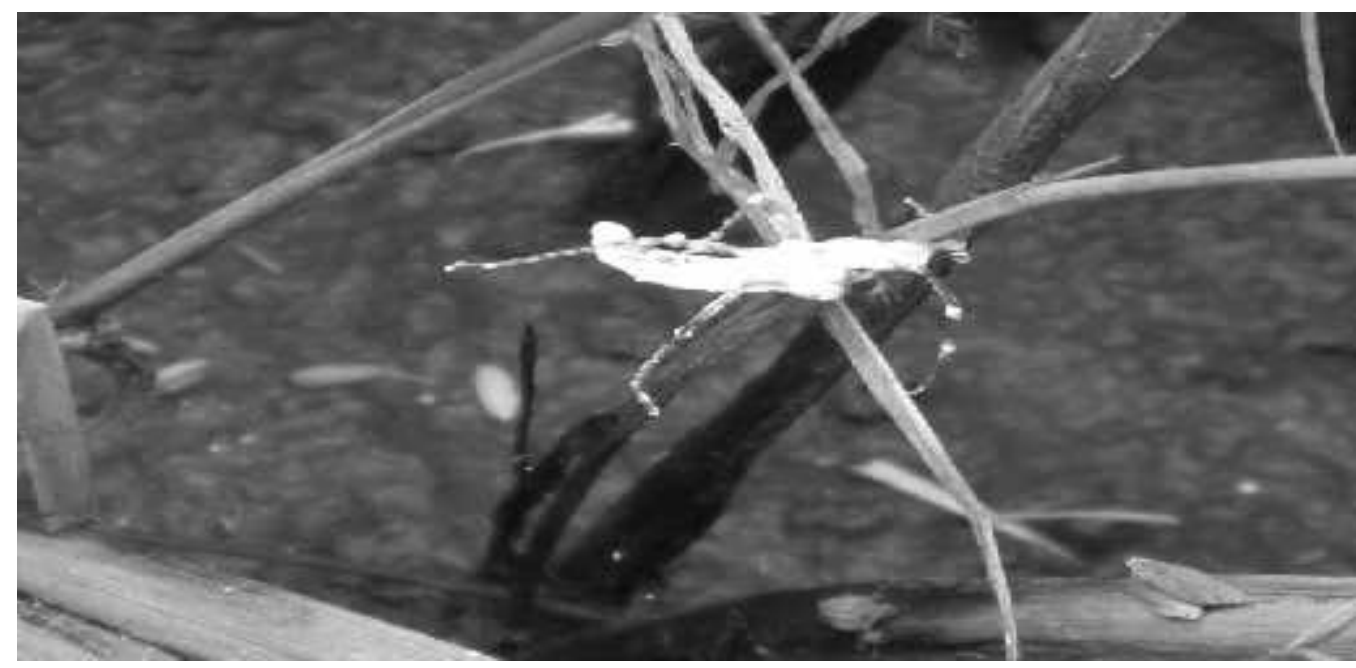

Gambar 1. Cendawan Patogen yang Menginfeksi L. oratorius Pada Tanaman Padi Sawah

(Figure 1. Pathogenic Fungi that Infect L. oratorius on Rice Plants) 




Gambar 2. Mortalitas Imago Setelah diaplikasi Beauveria sp.

(Figure 2. Mortality Imago Once Applied Beauveria sp.)

Tabel 2. Rata-rata Mortalitas L. oratorius oleh Cendawan Patogen Beauveria sp. dan Fusarium sp.

(Table 2. The average mortality of $L$. oratorius by the fungus Beauveria sp Pathogens. and Fusarium $s p$.

\begin{tabular}{llc}
\hline No & Cendawan & Mortalitas (\%) \\
\hline 1 & Beauveria sp & $30,03 \%$ \\
2 & Fusarium $\mathrm{sp}$ & $3,33 \%$ \\
\hline
\end{tabular}

Miselium muncul pada bagian ruas atau segmen dari hama tersebut, terutama bagian toraks dan kepala. Hasil pengamatan hama $L$. oratorius yang terinfeksi Beauveria sp. menunjukkan bahwa pada hari ketiga mulai nampak miselium muncul pada permukaan tubuh hama $L$. oratorius. Adanya miselium atau hifa pada serangga hama $L$. oratorius, setelah hama $L$. oratorius mati. Hama $L$. oratorius yang mati oleh Beauveria sp menjadi kaku dan mudah remuk. Cendawan B. bassiana memproduksi Beauvericin yang mengakibatkan gangguan pada fungsi hemolimfa dan inti sel serangga inang. Seperti umumnya jamur $B$. bassiana menginfeksi serangga inang melalui kontak fisik, yaitu dengan menempelkan konidia pada integumen. Perkecambahan konidia terjadi dalam 1-2 hari kemudian dan menumbuhkan miselianya di dalam tubuh inang. Serangga yang terinfeksi biasanya akan berhenti makan sehingga menyebabkan imunitasnya menurun (Deciyanto dan Idrayani, 2008). Kematian L. oratorius oleh Beauveria sp dikarenakan adanya senyawa kimia Beauvericin.

Masih rendahnya mortalitas $L$. oratorius oleh Beauveria sp, dimungkinkan karena konsentrasi spora yang digunakan masih tergolong rendah yakni $1 \times 10^{8}$. Bila konsentrasi spora cendawan dinaikan besar kemungkinan dapat mencapai di atas $60 \%$. Nilai mortalitas $L$. oratorius masih lebih tinggi dibandingkan yang dilaporkan Assa dkk. (2009) bahwa Beauveria sp mampu mematikan imago $L$. oratorius sebesar $18,4 \%$ pada konsentrasi $1 \times 10^{8}$. Mortalitas $L$. acuta pada kedua cendawan tersebut disajikan pada Tabel 2.

Suryana dan Erviana (2001) melaporkan bahwa suspensi spora $10 \mathrm{gr}$ dan $1000 \mathrm{ml}$ air mampu mematikan kepinding tanah, Scotinophara coarctata. Cendawan Beauveria bassiana mampu mematikan hama kepinding tanah $57,1 \%$ lebih tinggi daripada Metarhizium anisopliae 42,9\%. Berbeda yang dilaporkan oleh Rimbing dkk. (2007) bahwa mortalitas wereng hijau tertinggi ditemukan pada Metarhizium sp 91,25\%, dan Beauveria sp. $86,25 \%$. Kemampuan Beauveria sp terhadap hama-hama tanaman pertanian sangat dipengaruhi oleh jenis hama inang, dan strain dari cendawan tersebut. Dari segi ukuran kedua jenis serangga hama tersebut berbeda, sehingga tingkat mortalitas kedua hama tersebut berbeda. Hama $L$. oratorius jauh lebih besar dibandingkan dengan wereng hijau. 
Sebagaimana yang tercatum pada tabel 2 bahwa mortalitas $L$. oratorius yang tertinggi ditemukan pada Beauveria sp dibandingkan dengan Fusarium sp. Dalam kaitan dengan program pengendalian hama dengan memanfaatkan agen hayati seperti cendawan pathogen Fusarium sp sulit untuk dikembangkan sebagai agen hayati untuk mengendalikan hama $L$. oratorius, dikarenakan mortalitas $L$. oratorius pada tingkat laboratorium sangat rendah hanya mencapai $3,33 \%$. Hongke (1983) melaporkan bahwa Fusarium sp mampu menginfeksi serangga dari golongan Lepidoptera dan Homoptera. Fusarium sp mampu membunuh wereng hijau dan wereng coklat sekitar $51-80 \%$.

Pada tingkat laboratorium Beauveria $\mathrm{sp}$ mampu membunuh hama $L$. oratorius mencapai 33,3\%, namun keefektifan cendawan Beauveria sp. di lapangan masih perlu dilakukan pengujian di lapangan, sehingga diperoleh data tentang efektifitas cendawan Beauveria sp tersebut. Pengujian di laboratorium atau green house suhu dan kelembaban sangat stabil, serta tidak ada sinar matahari. Untuk di lapangan banyak faktor yang mempengaruhi terhadap virulensi cendawan tersebut dalam menurunkan populasi hama di lapangan. Belum tentu bahwa mortalitas imago $L$. oratorius di laboratorium $33,3 \%$ oleh Baeuveria sp. berlaku pula terhadap mortalitas $L$. oratorius di lapangan.

\section{KESIMPULAN DAN SARAN}

\section{Kesimpulan}

Cendawan patogen yang menginfeksi hama $L$. oratorius di Kabupaten Minahasa Selatan adalah Beauveria sp. dan Fusarium sp. Kemampuan cendawan patogen untuk membunuh imago hama $L$. oratorius tertinggi ditemukan pada Beauveria sp 30,03 \%, dan Fusarium sp hanya $3,33 \%$. Cendawan patogen yang berpontensi untuk dikembangkan sebagai agen pengendalian hama $L$. oratorius adalah Beauveria sp.

\section{Saran}

Perlu dilakukan uji efektifitas cendawan patogen pada stadia telur; perlu dilakukan pengujian kembali ditingkat laboratorium pada konsentrasi yang cukup tinggi untuk cendawan patogen
Beauveria sp. dalam menunjang pengujian cendawan patogen di lapangan; masih perlu dilakukan penentuan $\mathrm{LD}_{50}$ dan $\mathrm{LD}_{95}$ cendawan Beauveria sp terhadap $L$. oratorius

\section{DAFTAR PUSTAKA}

Anonim. 1990. Musuh Alami Organisme Pengganggu Tanaman Padi. Direktorat Jenderal Pertanian Tanaman Pangan. Direktorat Bina Perlindungan Tanaman. Jakarta.

DeBach, P. 1964. Succes, Trends and Future Possibities. In Biological Control of Insect Pest and Weeds. Ed.by P. DeBach. Reinhold pub, crop. $844 p$

Decianto, S dan G.A.A. Indrayani. 2009. Jamur Entomopatogen Beauveria bassiana : Potensi dan Prospeknya dalam Pengendalian Hama Tungau. Balai Penelitian Tanaman Tembakau dan Serat. Malang, Indonesia

Djuwarso, T., Supratoyo, A. Sultohoni dan M. Iman, 1989. Preferensi Walang Sangat, Leptocorixa acuta Fabricius pada Rumput dan Teki serta Serangannya pada Padi. Penelitian Pertanian. Balai penelitian Tanaman Pangan Bogor.

Hall, T. M. 1973. Use of Microorganisme in biological control. Biological of insect pest and weeds Chapman and Hall Ltd London P. 610-628.

Kalshoven, L.G.E. 1981. The Pests of Crops In Indonesia. PT. Ichtiar Baru Van Hoeve. Jakarta.

Rimbing, J., M. Manengkey dan M. Ratulangi. 2006. Keanekaragaman Jenis Cendawan Entomopatogen Lokal dan Tingkat Patogenisitasnya pada Hama Wereng sebagai Vektor Virus Tungro pada Tanaman Padi Sawah Di Sulawesi Utara. Fakultas Pertanian.

Rombach, M.C ., D. W. Roberts and R. M. Aguda. 1994. Pathogen of Rice Insect. In E. Aheinrichs. Biologi and Management of Rice Insect. International Rice Research Institute. 
J. Rimbing, M. Ratulangi., M. Meray. 2000. Pemantauan dan Peramalan Organisme Pengganggu Tanaman Pangan di Sulawesi Utara. Fakultas Pertanian Unsrat Manado

Suryana, T. dan Lilya Erviana, 2001. Pengendalian Kepinding Tanah Scotinophara coarctata dengan Cendawan Entomopatogenik. Prosiding Simposium, Pengendalian Hayati Serangga. Perhimpunan Entomologi Indonesia Cabang Bandung, Bandung.
Tohidin, A., T. lisrianto, Bey. P. Machdar, 1993. Daya Bunuh Jamur Entomopatogen Beauveria bassiana (Moniliales; Moniliacea) terhadap Leptocorixa acuta Thunberg (Hemiptera; Alydidae) di Rumah Kaca. Posiding Makalah. Symposium Patologi Serangga I. Yogyakarta. 
